\title{
中国における庭園舗装の特色
}

\section{Feature of the Garden Pavement in China}

\section{河原 武敏 \\ Taketoshi Kawahara}

Key Words 1. 特色 2. 庭国舖装 3. 中国

1.Feature 2.Garden Pavement 3.China

\section{はじめに}

わが国の飛び石や延段など簡明で洗練さ れた庭園舗装に比較して、中国のそれは「花 街舖地」と称されるように、その精緻な図 案模様に驚く。その理由について樋田直人 は《中国の暮らしと文化》で「中国では“地 面”は必ず人間が造らなければならず、こ れが中国の庭園美の根底にある。“道”は祖 先（先人の足跡）を意味しており、それは 尊び美化するものである。足元の「地」に 美しい卵石・小石、砂岩の青石や遠方加 色石老取り劄せ、更に人工の磚や白磁片で 大地にちりばめ教き詰め、華麗な文様を造 った。これが「舗地」である。と説明して いる。

したがて中国庭園を理解寸るには、技法 のほかに暮らしの文化に対する知識は欠か せない。本文はこうした要求をふまえ庭園 舗装の沿草、計画の基本的な考之方、その 種類と工法を考察して特色を明らかにする。

\section{1. 沿革}

休に舗装寸る里由は、湿気や土埃定防ぐ ためである。太古の住居は「“茨茅土階”（し ぼうどかい）と称さ侊、地面に蓠老敷いて
座る生活である。しかし冠をつけた貴人に はふさわしくない」とされ、土に石灰をま ぜた三和土を用いていた。やがて椅子の生 活が始まっても湿気と土埃の問題が解決し ないため、士を焼いた紅焼土を用いたが、 やがて工法の煩雑さから磚敷きが工夫され た。

碍舗装の沿革は《中国古代建築技術史》 に詳しいので、その概要を紹介してみよう。 初見は西周（B C 1044-771）末の陝西省扶 風県斉家区黄堆公社である。大きさは約 50 $\times 50 \mathrm{~cm}$ 、底には滑り止めらしい半乳顥の突 起物があった。河南省新鄭県鄭韓古城遗跡 から出土した磚にも底に辺稜の付いており、 その大きさは $34 \times 39 \mathrm{~cm}$ と $35 \times 47 \mathrm{~cm}$ 、表 面には米字紋・縄紋がつ叶られていた。

文献上は春秋時代の《書経》に「篦（傅） の上手道」とあるが詳らかでない。戦国時 代の河南省新鄭倉城遺跡には低温焼上で耐 磨性の低い紅焼上が発見されている。

秦代には傸西省咸陽宮遺跡から長辺にほ ぞ〔子母榫〕の付いた鋸菌形平行線紋碍が 出士し、その大きさは $55 \times 33 \times 5 \mathrm{~cm}$ 、平消 な仕上げではあるが製作が難しく、あまり 使われなからたようである。付近の唒安市 
瀶潼県秦俑坑の長廊には雨端が楔状で噛 み合わせのよい条磚の工夫が見受けられた。 漢代に入ると望都一号墓に連結しやすい 扇形傅や広州造船工場遺跡には $70 \times 70 \times$ $12 \sim 15 \mathrm{c} \mathrm{m}$ の大型碍が出土し、底には幾つ かの小孔があり焼上げを容易にしている。 しかし秦漢時代になると異形碍は次第に淘 汰され、方傅（正方形の䃀）と条磚（長方 形の碍）が一般に普及し、研磨技術と継ぎ 目に石灰を用いた接着剂が使われると、工 法が容易になり工事量も増大した。

唐代には舗装技術が高度に発達し、西安 市の長安大明宮に上面が大きく下面がやや 小さい磚が工夫され、継ぎ目（目地）の断 面が二角になるため、地盤と堅固に密着し 目地が見えないほどである。表面もまたが 平滑で防湿效果に優れていた。

宋代にもこのような磚が用いられ、当時 の技術畫《営造方式・巻 15》5）に「傅面 の四面はあらか心゙め研磨し、定規を用いて 正確に仕上げるべきだ」と記載されている。

明清時代に至ってもこの技法が継承され、 更にセメント 1 に砂 3 の割合に混合した粗 モルタル目地〔粗灰泥〕が使用され、宮廷 では目地に白セメントや石旁〔白灰霄〕が 注入されるようになった。

\section{2. 園路計画の基本}

\section{(1)迁回曲折の妙を見せる。}

一般に園路の目的は速やかに目的地に到 達させることにある。そのため軸線を設定 して荘厳美や一整美を演出する直線路を用 いるが、庭園で景観の趣賞するには、迁 回屈折路とすることが大切で、「移歩暴景」

の手段として重視されている。

明末清初の計成《園治》には「地形に従
つて屈折し、或は簏をう衫り、或は水辺で 止まり、花の中を通り、谷を渡り、蜿蜓と して尽きることがない。ようにするため、 園路は低きから仰ぎ、高きから俯瞰し、方 向を転じ、絶えず視線の角度と高さを変化 させる必要性を説いている。

更に清代の李漁《閑情寓劄》は「凡之迂 回する路を造るのは、特に趣きがあるから である。それは恰も門に脇門を設けるのと 同様で、急用な時にすぐ開き、そうでない 時は閉められる。これは俗雅ともに利があ り、理にも趣きにもかなっている」と通用 門の開閉に例えている。

\section{(2)自然の趣をもたせる。}

園路の計画には自然を貴び、その趣を反 映させる。ここでいう自然の尊重とは、地 势に合わせることで、自然環境すべてと融 合するよう人工らしさを見せまいとするも のである。明代の鄭元《影園自記》には「庭 園は広いといっても数婻にすぎないから、 計画しきれないという心配はない。山道が あっても起伏がないから舆で行ける。それ でも自然がひっそりと曲がりくねり、人工 のようには見えない」と自然の趣を最大限 に利用した庭園で女ると自讃している。

\section{(3)路面に装飾効果を与える}

前項とは逆である。これは園路自体が目 立った装飾效果を持ち、園路全体が一つの 景となるよう取り扱われることである。こ の效果は他の人工物と関連させ、庭園の雷 美的な要求を满足させるもので、条件に従 い様々な材料を用いて各種模様が舗装され る。これは「花街舗装地」と称され、中国庭 園施設の頙著な特色の一つとなっている。 例えば北京の故宮御花園には700 余種ある といわれ、その題材には様々な吉祥図・歴 
史伝説・民間寓話などが用いられている。

\section{(4)庭園景誽を誘導する}

園路計画は自然の地勢に順心し、その場 所の意趣を採り、庭園景観に自然美と人工 美密接に関連させることである。これに 就いて章采烈は《中国園林芸術通論》に「景 によって路を設け、路によって景を得る」 と園路計画の原則を述べている。園路は交 通路であるばかりでなく庭園景観の鑑賞を 誘導し、絵巻のように景区・景点を来園者 の前面に展開させる役目を持つので、計画 には変幻自在性を配虑している。例えば回 遊路線の大小複数設置により、景観の隅々 まで誘導させ、さらに市街地庭園の限られ た空間に多重の変化を与えることができる。

\section{3. 舗装の種類}

\section{(1)方磚舗装}

碍には城壁用の大きな「城碍」、四角の「大 方碍」、「小方磚」、「長方碍」があり、他に 南方でよく使われる垂木上の薄い「望板傳」、 さねはぎ付きで継ぎ目のある「企口碍」、表 面を磨いた「磨礵」などがある。建築内部 には正方形の「方䃌」が敷かれ、これには 「実舗」と「空舗」の二種類あり、実舗の 工法は(1)原地盤学付き固めた後、(2)砂地業 の上に方碍を敷き、(3)目地を礭粉と桐油を 混合した〔油灰〕で固着させ、(4)傷を補修 してから表面を磨き上げる。空舗の工法は 湿気を防ぐため地中壁を積んでから敷き詰 めるもので、工費が高く、内部に空洞があ るので集中加重に注意する。磿碰柱内用 で《園治》には「凡建物の床面と路、庭 園と住宅内の舗装は違う、思うに庁堂や大 きな室内では磨碍で舖装寸る。とある。

\section{(2)各種磚舗装〔諸磚地〕}

大小様々な磚材を用い、美しい慔様を作 る舖装をいう。《園治》には「磚を时いた舗 装模様に様々あるが、屋内では磿いた傳を 平らに舗装し、屋外の庭では磚を縦に小端 立て〔队湖〕するとよい。これによって作 られる様々な模様のうち方勝・畳勝・歩々 勝活古代で常用され、現代では人字・萃䋌・ 間方・紋斗紋がり、磚の長短を適宜按配し て用いるべきで、その様式は次のようであ る。」とあり、園内では地盤の変化に対忍し やすい磚の小端立てを使用すべきとしてい る。続いて「香草辺式: 碍で縁を作り瓦で 香草、内部に磚や鶖卵石で舗装したもの。 手門式: 玨卵石を縁取り内に嵌めこんだ舗 装したもの。波紋式：壞れた瓦の厚薄に従 って小端立てした舗装で、波頭には幅の厚 いもの、波横には薄いところが用いられ

\section{る。とある。【図 1】}

「方勝」は方形の斜め組多合わせわせ、「甾 勝」は方勝を複合したもの、「歩々勝」は方 形と斜形を連続した模様で昔から使われて いた。「人字」「蒂紋」「間方」「斗紋」は磚 を小端立てした模様である。更に小端立て た碍枠に黛卵石を詰妨た「六方式」「儹六方 式」八方間六方式」「套六方式」「長八方式」

「方式」「海棠式」「四方間卜字式」が図 示されている。この中の「攢」は聟せ集め、

「套」は一組をいう。

\section{(3)乱石舗装[乱石地]}

高低屈折する園路に最適な舗装。石面が 小さく塑性が大なので地形の制限を受けに くい。工费が安く施工容易で野趣に笛む。 計成の《園治》には「乱石路 庭園舗装に 小乱石を用いた石榴状のものは堅固で趣が ある。路が屈折上下し山から谷へ行く所に はこの方法がよい。瑟卵不の模様はかえっ 
て堅固にならない」と記している。

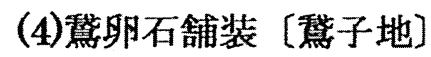

瑟鳥の卵に似た大小楕问形の石を縁取り した枠内に詰めた舗装である。表面に山凸 が多いと歩き難くなる。一般に人通りの多 い所には適しないし施工も難しい。㖕成の 《園冶》には「眚子地 鵟卵石は人が余り 歩か女所の舗装に用いるべきで、それには 大小の不で間をとって舗装するとよい。し かし普通の㦹人では作れ始配がある。ま た傅や瓦を用いた样々な錦紼模様もよいが、 鶴、蝔、猸子と毛鞠をかたどった舗装は「虎 を画いて犬に似る」ようで笑止である。と ある。《園治》の書かれた明未清初の時代を 降ると江南の庭園には動植物の意匠が多く 兒受けられる、中国独自の伝統的な寓意に よるものである。

\section{(5)氷裂舗装 [承裂地]}

青色石板や割れた方碍を組多合わせて作 る水裂模様の舗装である【図 2 】。廃物の碍 などを磨き直したもので题がある。計成の 《園治》に注「青石の板石破片で水裂模様 を舖装する所は、山の斜面、水辺の堤、台 の前や亭の近くがよい。この様式は風空の 項でも述べたように任意でよい。舗装は格 式に拘らず、烄れた碍を平らに磨いて舖装 すればなお好い。」とある。この種の石材は 溥く、底の多くは平らでないから円凸のな い上う仕上げに注意する。表面は油圧で嚙 出し、目地はノ口〔漿〕を措め、水が浸为 人ら姑よう注意して施工し、春先の凍結溶 解に上る崩壞防止に唒慮する。

\section{(6)各種模様舗装[花街舗地]}

様々な材料で色彩豊かな模様を作る舖装 である。清代の姚承祖が《造営法原》には じめて「花街舖地」という用語定用い、現在
は一般化され、蘇州では「泵」ともいわれ ている。

その位置・材料・模様について計成の《園 治》は「想うに庁堂や大きな部屋には磨磚 を用い、小路、曲路では多種の長乱石を、 中庭では畳勝がよいこともあり、手近な階 段には回紋でもよい。八角形の枠に鵟卵石 を選んで嵌めこむと蜀錦のようである。層 楼の平台に花の梢を彫れば、秦台を想わせ ることが出来る。その錦の線は瓦片で作り、 台面は平板で平らに舗装する。かくて花の 中で詩を吟ずる所となり、月下に酒を汲む 時には䋐掞を敷いたようになる。壊れた瓦 片を役立たせるには、太湖石を削って一緒 に舗装するがよく、かくて波が摇らめく様 相となる。壊れた方䃌も使うべきで、禁い て梅花を舖装したり、乱形の水裂模様を作 ることが出来る。とある。

舗装位置恃室内のほ力園路、中庭、階段、 層楼の平台、一般の台がよく、材料には磨

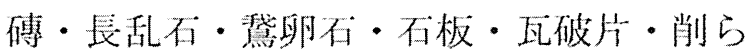
れた太湖石・方傳片。舖装模様には「畳勝」

「回文」「蜀錦」「波紋」「水裂」が示されて いる。この中の「回文」は回字を反復した 模様。「蜀錦」は四川省錦江産で䴗し系定織 った精繳華麗な織物模様をいう。「秦台」は 仙女の楼む所または豪華な秦玉の台。最後 の「梅花」は水雪の寒気に耐える高潔感な 君子の覀意をもつ。

この他に(3)黛卵石舖装の項で述べたよう な動植物などの模様がある【図 3 】。これに は瓦片のほか心紆・赤の臂片、白磁片、青 磚、白・黄・黑・藍の卵不、青弹不、弹石 片，藍不など様々な材料を用いた精繳華麗 な図案だが手間のかかる高価な舖装である。 題材は伝統的な寓意に上るもので、動物に 
は蝙蝠・鹿・鶴・龍・鳳凰など、植物には 松・竹・梅・蓮。万年青（おもとと）など、 文字には福・寿などがある。「蝙蝠」の蝙は 幸福の福と同音、「鹿」は快楽の楽と同音。

「竜と鳳凰」は瑞祥。「松と鶴」は長寿。「竹」 は高潔。「蓮花」は污い泥（世の中）に咲く 清い人格に羉えられ、いずれも自然界の生 物が使われている。

\section{4 . 庭園舗装工法と実例 (1)園路舖装の構造}

車馬人行する園路には衝撃王と摩損に対 する考慮が必要である。その要求にしたが って穼代の技術書《造営法式》では「やや 広い園路には、左右雨端に 2 枚乃至 4 枚の 側磚を小端立てし、中央部分を虹の様にや や高く左右に勾配をつけて舖装する」とあ

り【図 4 】、前者を平敷き〔平舗㑡】、後者 虹面敷き〔虹面轠砌〕という2 種類を図 示している。このように采代に人ると方礵 と条碍の組み合わせた堅固な舖装が見られ るようになった。

舖装用の碍には素面碍之模様磚〔花碍〕 があり、後者は早くも戦国時代の山東省曲 阜に蔓草紋舖磚、秦代の咸陽宮殿遺跡など にも模様碍が出土している。

碍舖装の工法は(1)まず地篮学付き固めし た後、(2)砂を敷き、(3)艺の上に嘈を教いて 不陸のない上う压着し、(4)その目地をパテ 〔油灰〕で塞ぎ，(5)孔を補修したら、(6)表 面を磨いて仕上げる。凍結防止孞必要な北 方では、基礎に石灰と黄士を混ぜ合わせた [灰土]層、来た性〔糯米汁日灰〕が使わ れ、その躈厚さは現地に倣っている。

また碍舗装初め加ら水平に敖くと、歩 く所が磨耗して低くなるため、排水公配〔反
水披度〕をつける必要がある。穼代の《営 造方式》に上ると柱の閒堂高く、室内中央 部をやや低く舗装しており、この方法は明 清代にまで継承された。

室内舗装は六朝時代までの座式から唐代 の椅子式に変化ても、屋外の土埃が持ち込 まれた。その対策に先ず碍自体から土埃が 出ない平滑な無地傳が用いられ、また嘈に は吸水性があり、湿気を呼ぶので油脂類が 塗布された。北斉時代には屋根瓦の防水に 胡桃油、宋代の《営造方式》には黄腊色之 桐油を塗布した油磚瓦、明清代では表面に 薄く墨灰を塗り、乾燥したあと胡桃油また は生桐油が塗布されている。

\section{(2)犬走り舗装の構造}

「犬走り」とは、軒先の雨水が屋内に侵 入しない上う地盤よりやや高く建物沿いに 設けた舗装をいら。

商（殷）代の河南省安陽の殷墟や陝西省 岐山の酉周遗跡には、堅質な大小の卵石舖 装を主流としていたが、卵石は稯角が合い にくく、よい接着材がないため、雨水で崩 壞し易い欠点があった。そのため周囲に長 卵石や碍で小端立て、平磚で横から押さえ るエ法が工夫された。陝西省鳳翔県の先秦 宮殿遗跡、咸陽の宮殿遗跡のほか、山東省 曲皁の漢代宮殿遺跡にその例が見られる

\section{【図 5 】。}

このように卵石舖装は堅質で形も色も美 しいが、軒先の「滴水穿石」に弱く、モル タル〔粗泥灰〕の使用だけで維持管理が 困難になり、次第に傅舗装が用いられるよ 5になり、唐代の長安大明宮重玄門【図6】 と西挟城遗跡にその例が見受けられる。

\section{(3)花街舗装の構造}

絨毯模様のように華麗な庭園舖装【図 7】。 
その吅緻な仕上げに必要な土法はかなり複 雑である。劉敦楨の《蘇州古典園林》によ ると「昔の工法では地盤を固めたのち、細 かい土を厚さ $5 \mathrm{~cm}$ に敷き、その上に各種の 磚や石を敷き詰めて図案を作る」と述べて いる。

その施工は(1)地盤地業。(2)細土を厚さ $5 \mathrm{~cm}$ 敷く。(3)磚・条石・瓦片などで眓案模 様の枠を作る。(2)中に瑟卵石・各種色石・ 磁片等定敷き詰めて作られる。

\section{（4)代表的な庭園の園路舖装例}

（i 承徳の避暑山荘: 山区にある御道は車 馬交通用である。したがって表面には耐磨 性の高い花溯岩の長石[条石]が用いられ、 その施工は(1)基礎地盤を付き固めてのち。 (2)石灰と黄上を混合した[灰上] を 1.5〜3.0 $\mathrm{m}$ [1～2 歩] の基礎地業をし、(3)その上に 6〜 $8 \mathrm{c} \mathrm{m}$ の粗砂で排水公配をつける。(4)上 部に長さ $1-2 \mathrm{~m}$ 、愊 $50 \mathrm{c} \mathrm{m}$ 、擪さ $20 \sim 30 \mathrm{~cm}$ の長石〔条石〕学敷き詰める。

(ii) 北京の頤和園・御花園 : 方磚の雨側に 卵石舖装を敷いた園路で「花路」とも称さ れている【図8】。中央の方磚舗装は愊 2 $3 \mathrm{~m}$ 、耑側の卵石舗装は幅 $50 \mathrm{c} \mathrm{m}$ 。最初に 中央の方礵、後に雨側の卵石学数く。その 施上仕(1)石灰と黄上の混合上（灰上]を 1.5 $\sim 4.5 \mathrm{~m}$ （1～3 歩）に付き固め、(2)中央部 分の方傅敷き下部に石灰と砂〔白灰仯〕を 数き込为、仕上:がり高 50〜 60 c mに舗装す る。(3)同様に雨端の卵石敷き走舗装し、上 部に石㕄に水を加えて㩭排したモルタル [由灰獎]を注いでから表面をよく水洗い して仕上げる。

\section{結び}

中国庭園の舖装はわが国とそれと比較し
てかなり思い入れが深い。その理由は前述 したように「古来、道は“先人の足跡” と して尊ばれ美化されてきた」とある。日本 人にとって中国庭園の華麗きわまる舗装の 警きも、中国人の永年にわたる「暮らしの 文化」の現れであることに気付く。中国庭 園を真に理解するには、改めて庭園技法の ほかに基本的な生活習慣の研究が必要であ ろう。なお引用原文は省略した。以上

\section{主要参考文献}

1) 東洋文化研究会編《中国の暮らしと 文化》（樋田直人「12 中国庭園の美」 明石書店 2005 。

2）李魚《閉情寓寄》巻 4 居室部・甃 地 1671

3）中国科学院編《中国建築技術史》科 学出版社 1990

4) 劉敦楨《蕉州古典園林》中国建築工 業出版社 1979

5）計成《園治》広文書局有限公司中 華民国 72 年

6 ）童謇《江南園林志》中国建築工業出 版榭 1984

7 ）楊鴻勛《江南園林論》中国建築工業 出版社 2003

8）羅哲文《蘇州古典園林営造録》上海 人民出版社 1994

9.）章采列《中国園林芸術通論》上海科 学技術出版社２004

10)馮鐘平《中国園林建築》精華大学出版 会 1988

11)阮栄春《舗地の文様》(舗地・中国庭 園のデザイン I N A X出版 1995 12)余志超《紐説中国園林》光明日報出版 社 2005 


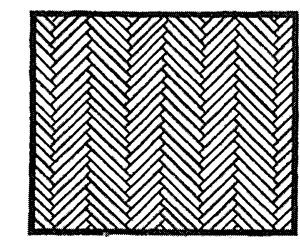

人字式

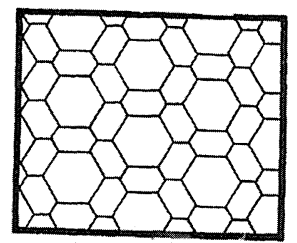

攢六方式

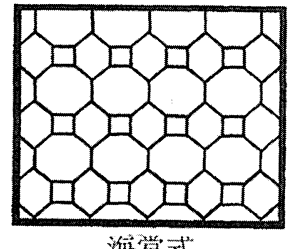

旅棠式

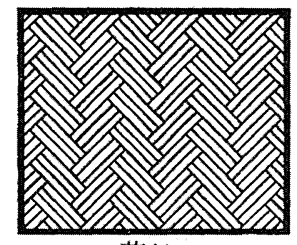

莿紋式

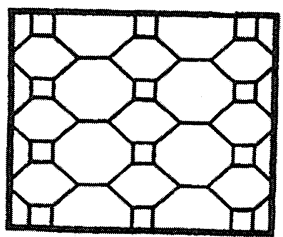

八方閒六方式

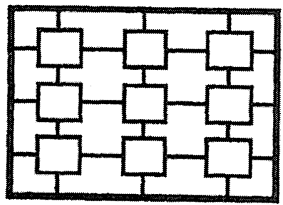

吃万間十字式

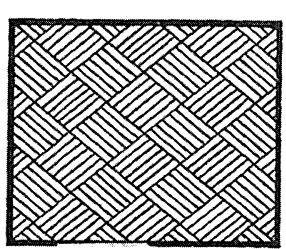

間方式

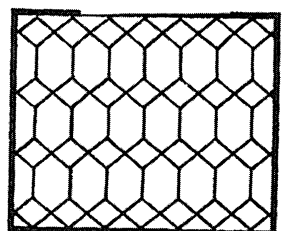

零六方式

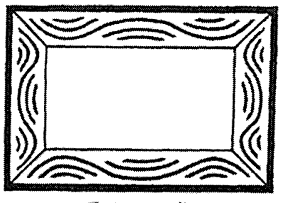

香草辺式

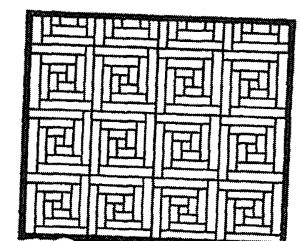

斗紋式

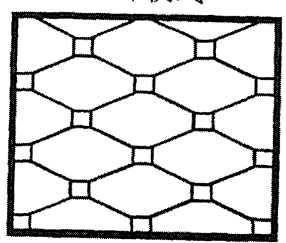

長八方式

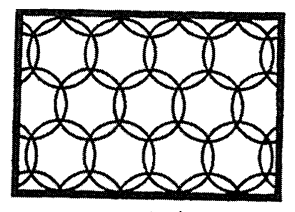

歬門式
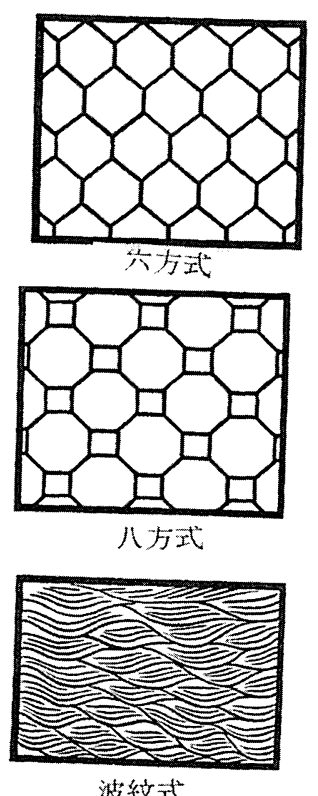

【図 1】計成《園绐》（廣文書局版）に見る䃌舖装

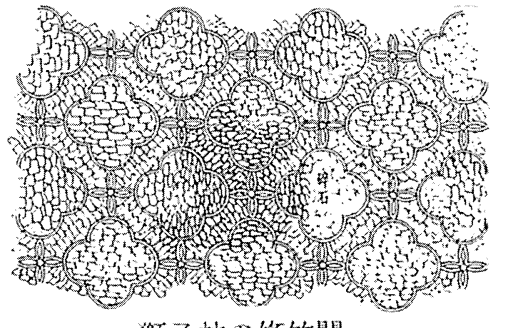

獅子林の修竹閣

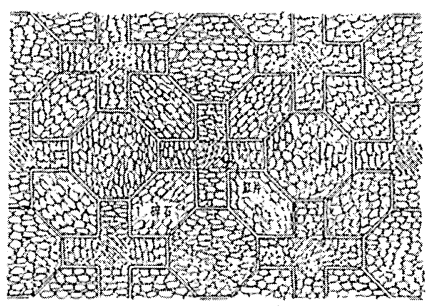

㢼意子林の䜩䈍堂

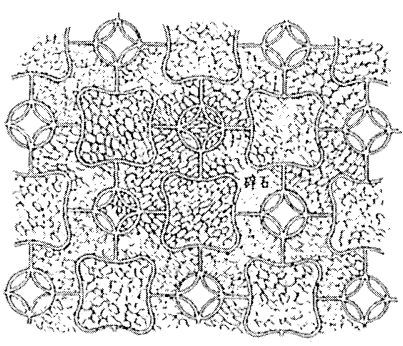

獅子林の古五松園

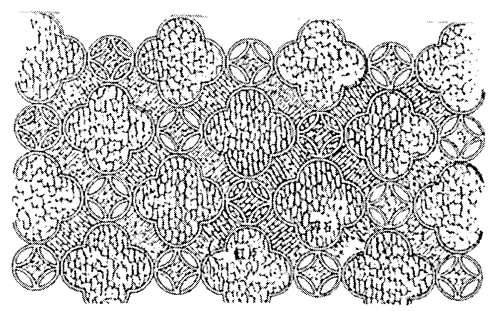

獅子林の燕誉堂

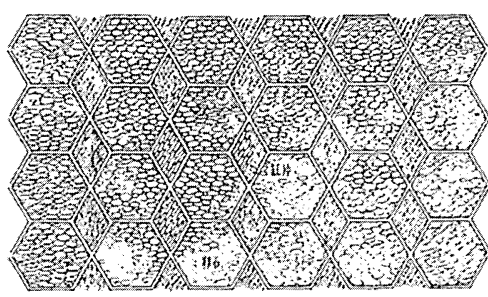

留園の一檑

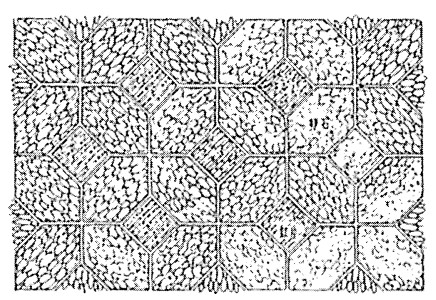

留固の一隅

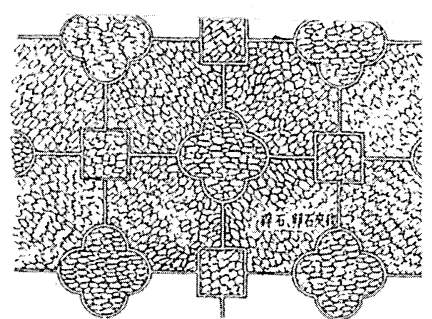

獅子林の指柏軒

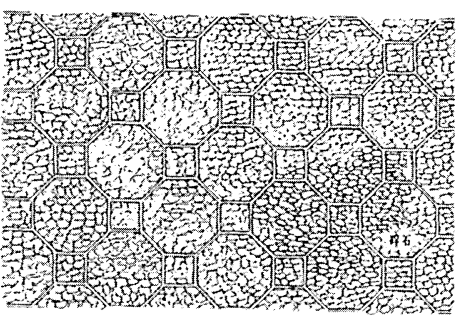

佃子陳の小方庁

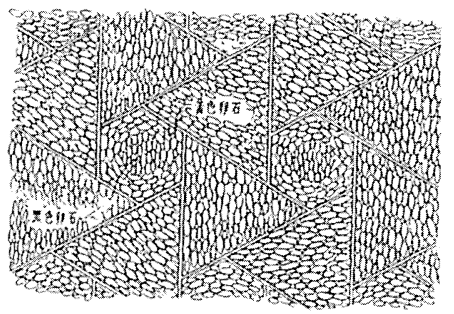

排政園の枇杷園

【図 7】蘇州の模様舖装例〔花街舗地〕(劉敦楨《蘇州古典園林》から作成） 

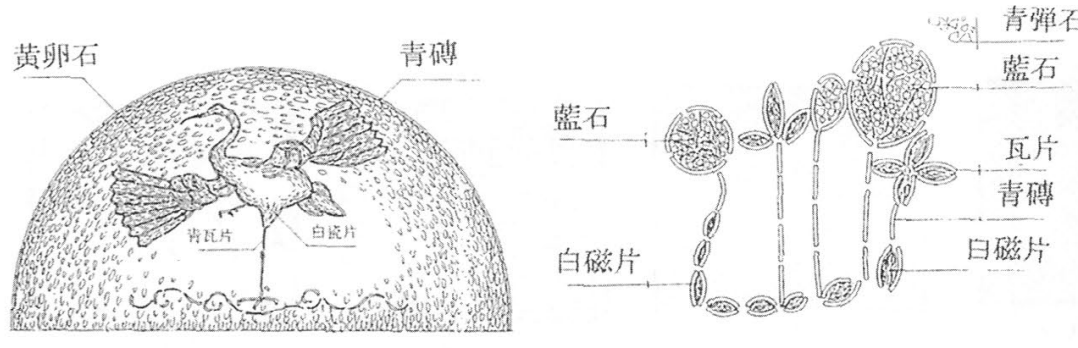

【図 3 】寓意による模様舖装（羅哲文《葆州古典園林造営録》から作成）

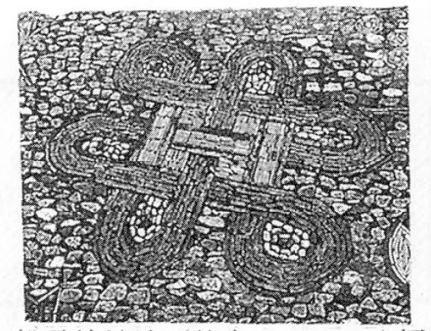

盤長紋舗地（仏宝の一つ・幸福崩）
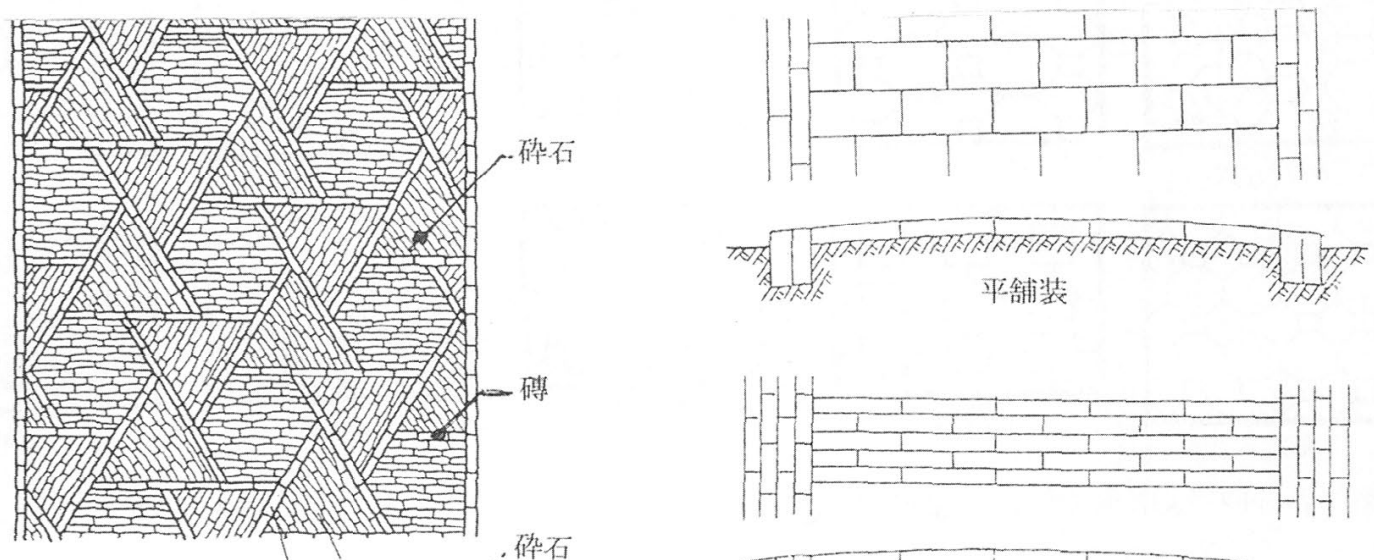

砂または石灰十砂〔白疢砂〕 地固め

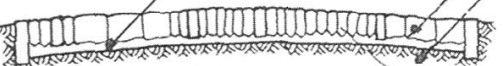

【図 2】水裂舗装の例——江南に多い「础石水栍路」 《中国古代建纂技術史》

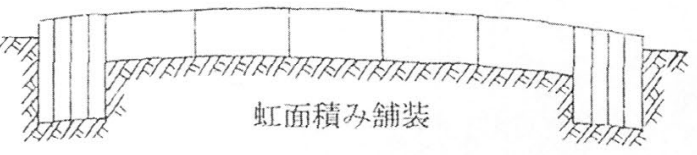

【図4】采代《営造方式》の磗舖装

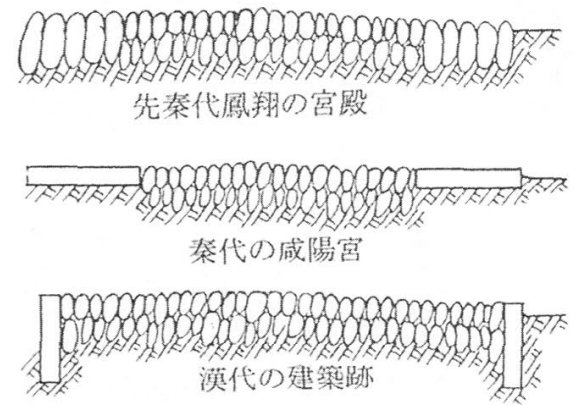

【図 5 】卵石製犬走りの遺跡例 《中国古代建築技術史》

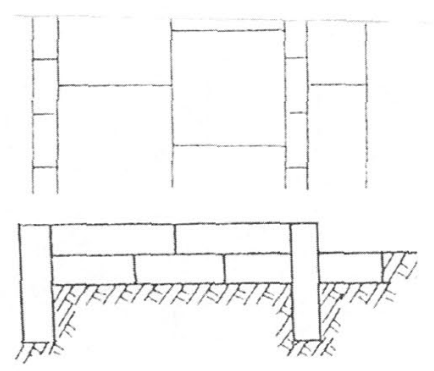

费代長实大明容重去門

【図6】方磷製犬走りの遗跡例 《中国古代建築技術史》
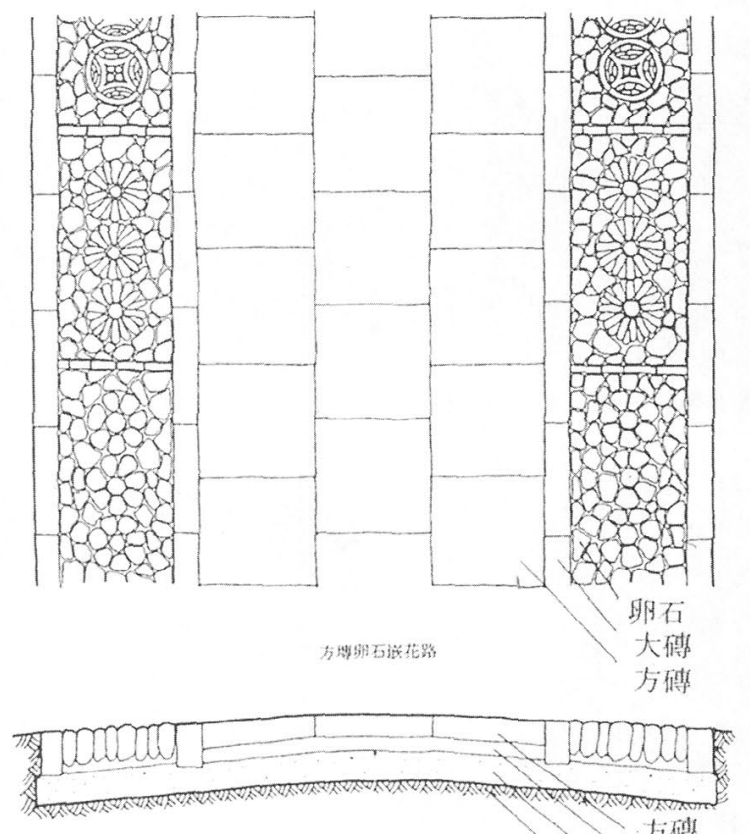

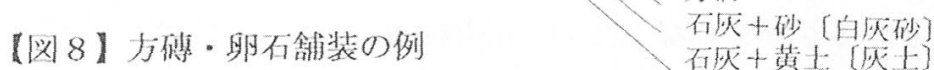

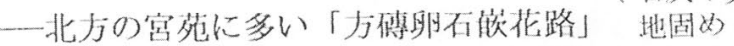

《中国古代建貿技術史》 